\title{
Environmental Corporate Social Responsibility (ECSR) As a Predictor of Consumer's Green Behavior
}

\author{
Siti Munerah ${ }^{1}$, Seethaletchumy Thambiah ${ }^{1} \&$ Saravanan Muthaiyah ${ }^{1}$ \\ ${ }^{1}$ Multimedia University, Malaysia \\ Correspondence: Siti Munerah, Multimedia University, Malaysia. E-mail: munerah.s@gmail.com
}

Received: September 19, 2018

Accepted: October 12, 2018

Online Published: October 15, 2018

doi:10.5539/ijbm.v13n11p241

URL: https://doi.org/10.5539/ijbm.v13n11p241

\begin{abstract}
The purpose of this paper is to explore the influence of environmental corporate social responsibility (ECSR) on consumer's green behavior. There is a lack of studies in the field of green consumer's behavior focusing on the impact of ECSR. This paper also explores the mediating effect of personal norm between the ECSR initiatives with consumer's green behavior. Based on norm activation model (NAM), personal norm acts as the mediator between activators of NAM and pro-social behavior. Numerous studies have been conducted utilizing personal norm as mediator to green behavior and the result from the studies have been positive. This study paper further explores the potential effectiveness of personal norm as a mediator between ECSR initiatives and consumer's green behavior. This concept paper offers significant contribution to the body of knowledge through exploring the potential impact of ECSR as well as the mediating effect of personal norm on consumer's green behavior. The findings in this study will create awareness among corporations the importance of highlighting corporate green initiatives among consumers.
\end{abstract}

Keywords: consumer behavior, green products, green initiatives, corporate social responsibility, norm activation model

\section{Introduction}

The topic related to the impact of corporate social responsibility (CSR) on consumer's behavior are often discussed, however, the environmental portion of CSR are often overlooked (Nik Ramli et al., 2014). There are three dimensions of ECSR according to Nik Ramli et al. (2014). The three dimensions are E-customer welfare, E-community involvement and E-philanthropy. E-customer welfare is an initiative by corporations that concerns about providing a complete product information to consumers that includes safety features and also provides green products in the market in order to reduce environmental deterioration. E-community involvement initiative focuses on the social aspect of CSR in terms of educating and getting engage in social and community involvement to promote programs related to environmental preservation. Finally, the third dimensions of ECSR is E-philanthropy. This type of initiative can be seen through generous financial contribution to non-profit organizations (NGOs) that promotes environmental preservation activities. The main drivers of ECSR are the deterioration of the environment caused by irresponsible business practice and unsustainable consumer behaviour (Lyon and Maxwell, 2008; Mazurkiewicz, 2008; Nik Ramli et al., 2014) as well as the generally rising concerns of consumers in general (Kalafatis et al., 1999; Kotler, 2011; Tiwari et al., 2011; Cherian and Jacob, 2012). The concept of ECSR is when a company combines environmental initiatives with its business operations as well as in dealing with stakeholders without compromising economic performance of the business (Nor Irwani et al., 2014).

This conceptual paper will explore each dimension of ECSR in the context of marketing point of view. ECSR is seen as a predictor to influence consumer's buying behavior through corporations marketing initiatives. Environmental deterioration is caused by constant damage from endless consumption, marketing, manufacturing, processing, discarding and polluting (Saha and Darnton, 2005; Gordon et al., 2011). According to Fry and Polonsky, 2004, firms engaged in marketing movement will impact on society in 'an unanticipated negative manner'. Marketing needs to become sustainable due to its impact on society (Gordon et al., 2011). Marketing has to play a practical role in sustainable development (van Dam and Apeldoorn, 1996; Peattie and Peattie, 2009; Gordon et al., 2011). Due to these concerns, corporations have to play a key role in changing the way they do business and also in changing consumer behaviour. Evidenced by the growing interest in sustainability issues, 
sustainability is now a mainstream issue (Bandura, 2007; Fitzsimmons, 2008; Gordon et al., 2011). Marketing provide tools to tackle these related issues as it plays a central role to influence behaviour (Gordon et al., 2011). Through marketing, corporations are able to communicate its ECSR initiatives to consumers. Increasing knowledge of corporate CSR activities leads to increased positive consumer attitudes towards the company as well as sales and profits (Wigley, 2008) and lack of that information is one of the barriers to purchase green products or products from responsible companies (Young et al., 2008). Marketing has the potential to deliver sustainability and it is often overlooked (Gordon, et al., 2011). The majority of the initiatives advocating sustainability have been executed upstream (Verplanken \& Wood, 2006; Gordon et al., 2011). ECSR tools are used by corporations to share information as well as knowledge regarding corporates' ECSR activities. Corporations ECSR initiatives include the promotion of sustainability from upstream to downstream of corporates' activities. Marketing is being use by corporations to promote sustainability (Gordon et al., 2011). ECSR has three dimensions and marketing tools are being used to fulfil these dimensions.

\section{ECSR and Consumer Behavior}

ECSR initiatives have been proven to positively influence corporate image among the consumer (Nor Irwani et al., 2014). ECSR also increases consumer's loyalty (Nik Ramli et al., 2014). Many consumers that buy green products are only interested to buy them from the companies they perceived to be environmentally responsible (Murphy et al., 2010). Sustainable marketing consciousness has positive influence on purchase intention as well as corporate social responsibility (Suki et al., 2016). According to Suki et al. (2016), marketing managers should optimize the opportunity given through budget distribution in corporate social responsibility to engage in sustainability for positive return of investment.

Firms realized their responsibility to environmental degradation and shoulder much of the responsibility but fundamentally it is consumers who demand goods and contribute to environmental issues (Polonsky, 1994). The patterns of consumers' consumption and behaviour are among the primary cause of environmental degradation (Tan, \& Lau, 2010). End-users are the key to ramping up sustainability and the only way to achieve environmental sustainability is by changing the consumer behavior (Wheeland, 2011). The current environmental impact cannot be reduced without changing the consumer attitude and behaviour (Lau, 2010; Olander, \& Thogersen, 1995). Even consumers have realized the impact of their purchasing patterns on the environment where one in five people believe that individual consumers are most to be blamed for environmental problems (Murphy et al., 2010). Even with the knowledge and awareness about the concept of being environmentally responsible, many consumers may not necessarily implement this idea to change to a more sustainable lifestyle (Jacob \& Cherian, 2012).

Research on corporate social responsibility may be at a mature stage but consumer responses to CSR initiatives are not. (Feldman \& Vasquez-Parraga, 2013, p.100). Sustainable business practices can influence consumer (Perella, 2013). Through product or service offerings, CSR practices, marketing and educational campaigns, corporations help consumers to be educated and conscious about sustainable consumption (Park \& Ha, 2012) by attempting to engage customers in environmental initiatives (Guziana \& Dobers, 2013). "Motivating consumers to adopt more sustainable consumption behaviors is an important policy goal ..."(Wells, Ponting \& Peattie, 2011, p.809). Caruana and Crane (2008) research on a website articulating sustainable vacation and travel found that corporate communications significantly influenced the process of constructing responsibility (e.g. highlights responsible tourist behavior that preserves the local environment and the consequences of being irresponsible tourists). Green campaign activities and eco-friendly products by green retailers influence positive impact on consumers' green consciousness and behavior (Lee et al., 2012). According to Bhattacharya and Sen (2004), consumer undergo some form of "behavior modification" based on certain types of corporate involvement in an issue that concerns about the society as a whole. "The influence of CSR-related attributes on consumers' purchase intentions is more complex than previously thought of, in that, CSR can affect purchase intentions directly or indirectly" (Khojastehpour \& Johns, 2014, p. 333). Some consumers base their buying decision on company's involvement in society and environment responsibility (Grimmer \& Bingham, 2013). Nik Ramli et. al. (2014) explored a portion of CSR initiatives particularly environmental initiatives on consumer behavior and stated that environmental initiatives increased consumer loyalty and enhanced corporate image. Company environmental commitment has the highest influence on the purchase decision of a socially responsible consumer (Feldman \& Vasquez-Parraga, 2013). There have been extensive studies in the extent literature pertaining to the challenges related to behavioral change (Gordon et al., 2011). Consumers have to realise the consequences of their actions. It is important for the consumers to understand and be aware of the impact of unsustainable production, consumption and disposal system by corporations and individuals (Peattie and Collins, 2009; Gordon et al., 2011). Corporations can expedite change via the execution of targeted and effective 
downstream and upstream intervention (Verplanken \& Wood, 2006; Gordon et al., 2011). The three elements of ECSR are being discussed in detail in this study. The elements of ECSR included in this study are eco label (e-customer welfare), environmental campaign or environmental advertising (e-community involvement) and cause-related campaign or cause-related marketing (e-philanthropy).

\subsection{Eco Label and Consumer Behavior}

Environmental labels or eco-labels are used by corporations to differentiate their products in the market place (D'Souza et al., 2006). It acts as a guide for consumers to choose products that reduce environmental impact (D'Souza, 2000; Rex \& Baumann, 2006) and enables them to influence how the product is manufactured (Rex \& Baumann, 2006). Eco label has also proven to be affective in raising awareness and trust as well as creating awareness among the consumer that a company has strived to be sustainable (Watanatada, 2011). It acknowledges the extensive dedication of companies in the management of preserving the environment, which are not always noticeable (Proto et al., 2007). It assures consumers of the truthfulness of these claims by providing certification marks or seals of approval (Atkinson \& Rosenthal, 2014).

Eco labels have proven to be affective to raise awareness and trust as well as creating awareness among the consumer that a company has strived to be sustainable (Watanatada, 2011). Eco label is perceived by consumers to be a critical factor when making decision to buy (Thorgersen, 2002; Zhu, 2013). The results of a survey indicate ninety-eight per cent $(98 \%)$ of consumers are familiar with the word "Recyclable" and states that eighty-eight per cent (88\%) of the respondents agreed that this would have an effect in their purchase decision (Murphy et al., 2010). Specific product label such as "Recyclable" enables companies to communicate products' benefits to consumers (Juwaheer et al., 2012). Eco labels are seen as a marketing tool to differentiate a product and to position a product image as green products in the market (D'Souza, 2004, Rex and Baumann, 2007). Positioning is paramount in guiding the formation of product values and beliefs in the minds of target consumer's cognition (Pickett-Baker and Ozaki, 2008). According to Nik Ramli et al. (2009), Malaysian consumers react positively to eco-label and consider it to be crucial during their purchase decision.

\subsection{Environmental Campaign and Consumer Behavior}

Environmental campaign or environmental advertising have several core elements which are; the presentation of the corporation's mission statement with regard to environment preservation, the process adopted by the company that makes it environment friendly, and a particular CSR activity related to the environment (Davis, 1994; Cherian \& Jacob, 2012). Environmental advertising or commonly known as green advertising is defined by Zinkhan and Carlson (1995) and as cited in Zhu (2013) as "the appeals that try to fulfil consumers' needs and aspiration regarding to environmental concern and health issues from different perspective including ecology, sustainability, and pollution-free messages" (p.72). The two dimensions of environmental campaign are education- focused and commercial-focused. Education-focused environmental advertising focuses to enhance and create awareness among the consumers towards the environment and nature, while commercial-focused environmental advertising is designed for the purpose of increasing sales of products or services and some concern for the firm's green image and customer loyalty (Banerjee et al., 1995; Menon et al., 1999; Zhu, 2013). This paper will focus on the education-focused of environmental campaign dimension and is integrated as part of ECSR initiatives dimension of E-community involvement.

The research by Davis (1994) suggested that environmental advertising or environmental campaigns has an effect on consumer's attitude towards corporations and their products. The environmental campaign by Unilever through the production of the short film called "Why Bring A Child Into This World" contained negative appeals. Negative appeal in advertising is used to influence consumers to feeling guilty or ashamed of their actions in contributing to environmental problems and other issues (Brennan \& Binney, 2008). A research conducted by Zhu (2013) on consumer's purchase intention of green product in relation to environmental advertisement showed that consumer's attitude towards environmental advertising played an important role in determining the level of intention of consumers to purchase green products. The positive perception of consumers on environmental campaigns and movements was an important determinant for consumers to go green (Rezai et al., 2013). According to Yang et al. (2015) consumers can be motivated by environmental advertising that uses abstract appeal and when it highlights the benefits of an individual's green consumption on others. A research by Abd Rahim et al. (2012) on environmental advertising by the Malaysian government has shown to have positive impact on youths to embrace the green concept. However, they have highlighted in their research findings that the government needs to be able to craft a better green messages and better execution of green campaigns. It was supported by Mei et al. (2012) that government environmental campaigns have significant influence on environmentally friendly purchase intention. 


\subsection{Cause-Related Campaign}

Cause-related campaign or cause-related marketing (CRM) is a partnership between business entities and non-profit organizations via sponsorship causes (Robinson et al., 2012; Mani Kanta et al., 2014). It may be done through a donation to a non-profit organization for each product sold by the company (Moosmayer \& Fuljahn, 2010; Anuar \& Mohamad, 2012). CRM promises its consumers to donate a worthy cause for every product sold (Douwe van der Brink et al., 2006). "Conceptually, CRM represents cause specificity of corporate social responsibility or CSR (Sheikh \& Beise-Zee, 2011). According to Nik Ramli et al. (2014), the third dimension of ECSR is E-Philanthropy. E-Philanthropy is the desire of an organization to promote the welfare of others and often expressed via a generous amount of donation to non-profit organization (NGO). Nik Ramli et al. (2014) reiterates that E-philanthropy can be seen in the providing of financial resources to execute initiatives that strengthen environmental consciousness and reactions from the public through partnership with the selected NGO or donation. CRM is used as an instrument to implement CSR causes (Kotler and Lee, 2005) and philanthropy is the central core of CSR (Peloza \& Shang, 2011; Nik Ramli et al., 2014).

Surveys show that consumers would view a firm positively if it supports social causes (Simmons \& Becker-Olsen, 2006) and this will lead to increased sales (Adkins, 2004; Shabbir et al., 2010). According to Douwe van der Brink et al. (2006), Strategic CRM is proven to enhance consumer loyalty and consumers prefer firms that implement strategic CRM in their CRM strategy. A study in Malaysia showed that CRM has significant impact on consumer attitudes and purchase intention (Anuar \& Mohamad, 2012). A study was also conducted in Pakistan and it showed positive results on consumer purchase intention with brand awareness and corporate image as mediating factors (Shabbir et al., 2010). The size of donations from corporations to non-profit organizations affects consumer cooperation towards CRM campaigns (Moosemayer \& Fuljahn, 2010) and according to Folse et al. (2010), consumers are inspired to support CRM campaigns due to socio-emotional reasons and economic reasons.

\section{Personal Norm as Mediator}

Personal norm refers to the "moral obligation to perform or refrain from specific actions" (Schwartz \& Howard, 1981, p. 191). Personal norms have been proven to be crucial in pro-environmental behaviour (see Kaiser et al., 2005; Biel \& Thøgersen, 2007). Pro-environmental behaviours are motivated by intrinsic rather than extrinsic reasons and the people who perform these behaviours are those who are doing it for the environment to benefit others (Ebreo et al., 2003). Personal norm focuses on a person's inner moral considerations (Zhang et al., 2013). According to Bamberg et al. (2007), personal norms are based on two related but distinct processes of anticipated feelings or guilt and perceived social norms. Personal norm has shown to be a significant predictor of energy saving behaviour in general (van der Werff \& Steg, 2015). Based on the study by van der Werff and Steg (2015) on energy behaviour, the stronger the personal norm, the more efficient one's driving style, water usage and meat consumption. Personal norm has been proven to influence intentions of behaviours (Steg and de Groot, 2010) especially pro-environmental behaviour (Zhang et al., 2014). Personal norm had positive influences on employee electricity saving behaviour (Zhang et al., 2013), choice of travel mode (Hunecke et al., 2001), recycling (Park and Ha, 2012), meat consumption and showering time (van der Werff and Steg, 2015), public transportation and energy use (Harland et al., 2007), total energy saving (Ambrahamse \& Steg, 2009) and organic milk purchasing (Klöckner \& Ohms, 2009). Personal norm contributes to pro-environmental behaviour such as green consumerism (Thøgersen, 1999). According to Bamberg and Schmidt (2003), personal norm itself does not lead to actual performing behaviour. However according to Park and Ha (2012), the intention to recycle depends on the individual personal norm pertaining to recycling activities. Personal norm correlates strongly with the intention to perform behaviour and it is used to predict individual personal feelings towards pro-environmental behaviour (Onwezen et al., 2014). Hofenk et al. (2010) highlighted that personal norm (PN) has the greatest effect on pro-environmental purchase intention.

Based on Schwartz (1977) Norm Activation Theory (NAT), an activated personal norm acts as a mediator between the activators and behaviour. During the development of the study, NAT was used to predict prosocial related behaviours. It has been expended to pro-environmental related behaviour by various researches (i.e. Ebreo et al., 2003; Ambrehamse \& Steg, 2009; De Groot and Steg, 2009; Brekke et al.,2010; Steg \& De Groot, 2010; Zhang et al., 2013; Han, 2014; Zhang et al., 2014; Lauper et al, 2015; Vaske et al., 2015; van der Werff, 2015). It has been proven by many researchers that personal norm mediates the relationship between all of the independent variables components of Norm Activation Model (NAM) that includes, awareness of consequence (AC), ascription of responsibility (AR) and efficacy. In a study on carbon mitigation, personal norm was tested to positively mediate the relationship between awareness of consequences (AC) and ascription of responsibility (AR) with ecological behaviour (Vaske et al., 2015). When tested for the assumption of the Norm Activation 
Theory that personal norm has direct effect on behavioral intention, it was proven to be positive and personal norm was proven to mediate other independent variables (Lauper et al., 2015). In another environmental field study related to pro-environmental spillover, the results of the study showed that personal norm mediates the spillover effect of pro-environmental behavior (Steinhorst et al., 2015). Based on these findings, personal norm has shown to have an important role to mediate relationships in the field of green behavior studies. Thus, it would give enough justifications for the role of personal norm as a mediator between ECSR and consumer's green behavior.

\subsection{The conceptual framework}

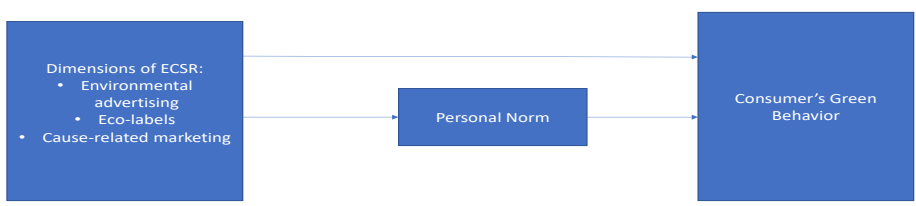

Figure 1. The conceptual framework

\section{Conclusion}

This conceptual paper presents the potential effect of ECSR as a predictor of consumer's green behavior and it explores the potential of personal norm that acts as the mediator between ECSR and consumer's green behavior. The dimension of ECSR that includes E-customer welfare, E-customer involvement and E-philanthropy are presented based on marketing point of view. Eco-labels, environmental advertising and cause-related marketing represents each dimension of ECSR initiatives. This study proposes that corporation's ECSR initiatives predicts consumer's behavior directly and via personal norm. When consumers are expose corporations ECSR initiatives, it triggers ones' moral obligation or personal norm and eventually lead to green behavior. It is hope that from this study, corporations will be aware of the importance of ECSR initiatives in influencing consumer's behavior towards sustainability.

\section{References}

Abd Rahim, M. H., Ros Zayanah, J., Fauziah, A., \& Lyndon, N. (2012). Green advertising and environmentally responsible behavior: The level of awareness and perception of Malaysian youth. Asian Social Science, 8(5), 46-54. https://doi.org/10.3359/ass.v8n5p46

Abrahamse, W., \& Steg, L. (2009). How Do Socio-demographic And Psychological Factors Relate to Households' Direct And Indirect Energy Use And Savings? Journal of Economic Psychology, 30, 711-720. https://doi.org/10.1016/j.joep.2009.05.006

Adkins, S. (2004). Cause-related marketing: who cares win. CSR the Business Case, 52-55.

Annuar, M. M. \& Mohamad, O. (2012). Consumer response to cause-related marketing: A case of Malaysia. Journal of Asian Business Strategy, 2(4), 71-76.

Bamberg, S., \& Schmidt, P. (2003). Incentives, morality, or habit? Predicting student car use for university routes with the model of Azjen, Schwartz, and Triandis. Environment and Behavior, 35, 264-285. https://doi.org/10.1177/0013916502250134

Bamberg, S., Hunecke, M., \& Blobaum, A. (2007). Social context, personal norms, and the use of public transportation: Two field studies. Journal of Environmental Psychology, 27, 190-203.

Barnerjee, S., Gulas, C. S., \& Iyes, E. (1995). Shades of green: A multidimensional analysis of environmental advertising. Journal of advertising, 24(2), 21-31.

Bhattacharya, C., \& Sen, S. (2004). Doing Better at Doing Good: When, Why, and How Consumers Respond to Corporate Social Initiatives. California Management Review, 47(1), 9-24. https://doi.org/10.2307/41166284.

Biel, A., \& Thogersen, J. (2007). Activation of social norms in social dilemmas: A review of the evidence and reflections on the implications for the environmental behavior. Journal of Economic Psychology, 28, 93-112. https://doi.org/10.1016/j.joep.2006.03.003 
Brekke, K., Kipperberg, G., \& Nyborg, K. (2010). Social interaction in responsibility ascription: The case of household recycling. Land economics, 86(4), 1-35.

Caruana, R., \& Crane, A. (2008). Constructing Consumer Responsibility: Exploring the Role of Corporate Communications. Organization Studies, 29(12), 1495-1519. https://doi.org/10.1177/0170840607096387

Cherian, J., \& Jacob, J. (2012). Green Marketing: A Study of Consumers' Attitude towards Environment Friendly Products. Asian Social Science, 8(12), 117-126.

D'souza, C. and Lamb T. P. (2006). An empirical study on influence of environmental labels on consumers. Corporate Communication: An International Journal, 11(2), 162-173. https://doi.org/10.1108/13563280610661697

Davis, J. J. (1994). Consumer response to corporate environmental advertising. Journal of Consumer Marketing, $11(2), 25-37$.

Davis, J. J. (1995). The effects of message framing on response to environmental communications. Journalism and Mass Communication, 72(2), 285-299.

De Groot, J., \& Steg, L. (2009). Morality and Prosocial Behavior: The Role of Awareness, Responsibility, and Norms in the Norm Activation Model. The Journal of Social Psychology, 149(4), 425-449. https://doi.org/10.3200/SOCP.149.4.425-449

D'souza, C. (2004). Ecolabel programmes: A stakeholder (consumer) perspective. Corporate Communication: An International Journal Corporate Communications: An International Journal, 9(3), 179-188. https://doi.org/10.1108/13563280410551105

Ebreo, A., Vining, J., \& Cristancho, S. (2003). Responsibility For Environmental Problems And The Consequences Of Waste Reduction: A Test Of The Norm-Activation Model. Journal of Environmental Systems, 29(3), 219-244. https://doi.org/10.2190/EQGD-2DAA-KAAJ-W1DC

Feldman, P., \& Vasquez-Parraga, A. (2013). Consumer social responses to CSR initiatives versus corporate abilities. Journal of Consumer Marketing, 30(2), 100-111. https://doi.org/10.1108/07363761311304915

Folse, A. G., Niedrich, R. W., \& Grau, S. L. (2010). Cause-related marketing: The effects of purchase quantity and firm donation amount on consumer inferences and participation intentions. Journal of Retailing, 86, 295-309. https://doi.org/10. 1016/j.jretai.2010.02.005

Gordon, R., Carrigan, M., and Hastings, G. (2011). A framework for sustainable marketing. Marketing Theory, 11(2), 143-163. https://doi.org/10.1177/1470593111403218

Grimmer, M., \& Bingham, T. (2013). Company environmental performance and consumer purchase intentions. Journal of Business Research, 66(10), 1945-1953. https://doi.org/10.1016/j.jbusres.2013.02.017

Guziana, B., \& Dobers, P. (2013). How Sustainability Leaders Communicate Corporate Activities of Sustainable Development. Corporate Social Responsibility and Environmental Management Corporate Social Responsibility. Environment Management, 20, 193-204. https://doi.org/10.1002/csr.1292

Han, H. (2014). The norm activation model and theory-broadening: Individuals' decision-making on environmentally-responsible convention attendance. Journal of Environmental Psychology, 40, 462-471. https://doi.org/10.1016/j.jenvp.2014.10.006

Harland, P., Staats, H., \& Wilke, H. (2007). Situational and Personality Factors as Direct or Personal Norm Mediated Predictors of Pro-environmental Behavior: Questions Derived From Norm-activation Theory. Basic and Applied Social Psychology, 29(4), 323-334. https://doi.org/10.1080/01973530701665058

Hofenk, D., Birgelen, M. V., Bloemer, J., \& Semejin, J. (2010). Integrating the theory of planned behavior and the norm-activation theory to explain pro-environmental buying intention. Institute for Management Research.

Hunecke, M., Blobaum, A., Matthies, E., \& Hoger, R. (2001). Responsibility and Environment: Ecological Norm Orientation and External Factors in the Domain of Travel Mode Choice Behavior. Environment and Behavior, 33(6), 830-852.

Juwaheer, T., Pudaruth, S., \& Noyaux, M. (2012). Analysing the impact of green marketing strategies on consumer purchasing patterns in Mauritius. World Journal of Entrepreneurship, Management and Sustainable Development, 8(1), 36-59. https://doi.org/10.1108/20425961211221615

Kaiser, F. G., Hubner, G., \& Bogner, F. X. (2005). Contrasting the theory of planned behavior with the 
value-belief-norm model in explaining conservation behavior. Journal of Applied social psychology, 35(10), 2150-2170. https://doi.org/10.1111/j.1559-1816.2005.tb02213.x

Kalafatis, S. P., Pollard, M., East, R., \& Tsogas, M. H. (1999). Green Marketing and Azjen Theory of Planned Behavior: A cross-market examination. Journal of Consumer Marketing, 16, 441-460. https://doi.org/10.1108/07363769910289550

Khojastehpour, M., \& Johns, R. (2014). The effect of environmental CSR issues on corporate/brand reputation and corporate profitability. European Business Review, 26(4), 330-339. https://doi.org/10.1108/EBR-03-2014-0029

Klöckner, C., \& Ohms, S. (2009). The importance of personal norms for purchasing organic milk. British Food Journal, 111(11), 1173-1187. https://doi.org/10.1108/00070700911001013

Kotler, P. and Lee, N. (2005). Corporate social responsibility: Doing the most good for your company and your cause. New Jersey, NJ: John Wiley \& Sons Inc.

Lau, T. (2010). Towards Socially Responsible Consumption: An Evaluation of Religiosity and Money Ethics. International Journal of Trade, Economics and Finance IJTEF, 1(1), 32-35.

Lauper, E., Moser, S., Fischer, M., \& Matthies, E. (2015). Explaining Car Drivers' Intention to Prevent Road-Traffic Noise: An Application of the Norm Activation Model. Environment and Behavior, 1-28. https://doi.org/10.1177/0013916515570476

Lee, N., Choi, Y., Youn, C., \& Lee, Y. (2012). Does Green Fashion Retailing Make Consumers More Eco-friendly?: The Influence of Green Fashion Products and Campaigns on Green Consciousness and Behavior. Clothing and Textiles Research Journal, 30(1), 67-82. https://doi.org/10.1177/0887302X12446065

Lyon, T. P., \& Maxwell, J. W. (2008). Corporate social responsibility and the environment: A theoretical perspective. Review of Environmental Economics and Policy Advance Access, 1-22. https://doi.org/10.1093/reep/ren004

Mani Kanta, K., Ramana, D. V., \& Mallikarjuna, V. (2014). Cause related marketing: Antecedents of corporate motive. SCMS Journal of Indian Management, 71-78.

Mazurkiewicz, P. (2004). Corporate environmental responsibility: Is a common CSR framework possible? working paper, World Bank, Washington DC.

Mei, O., Ling, K., \& Piew, T. (2012). The Antecedents of Green Purchase Intention among Malaysian Consumers. ASS Asian Social Science, 38, 39-43. https://doi.org/10.5539/ass.v8n13p246

Menon, A., Menon, A., Chowdhury, J., \& Jankovich, J. (1999). Evolving paradigm for environmental sensitivity for marketing programs: A synthesis for theory and practice. Journal of Marketing Theory and Practice, 1-15. https://doi.org/10.1080/10696679.1999.11501825

Moosmayer, D. C. \& Fuljhan, A. (2010). Consumer perceptions of cause-related marketing campaign. Journal of Consumer Marketing, 27(6), 543-549. https://doi.org/10.1108/07363761011078280

Murphy, R., Graber, M., and Stewart A. (2010). Green marketing: A study of the impact of green marketing on consumer behavior during recession. The Business Review, Cambridge, 16(1), 134-140.

Nik Ramli, N., Jusoff, K., \& Kassim, K. (2009). Eco-Labeling Perspectives amongst Malaysian Consumers. Canadian Social Science, 5(2). http://dx.doi.org/10.3968/j.css.1923669720090502.001

Nik Ramli, N., Rahman, N., \& Khalid, S. (2014). Environmental corporate social responsibility (ECSR) as a strategic marketing initiatives. Procedia - Social and Behavioral Sciences, 130, 499-508. https://doi.org/10.1016/j.sbspro.2014.04.058

Nor Irwani, A. R., Nik Ramli, N. A. R. \& Shaiful, A. K. (2014). Environmental Corporate Social Responsibility (ECSR): Exploring its influence on corporate image. Journal of Management Sciences, 1(2), 21-38.

Olander, F., \& Thogersen, J. (1995). Understanding of consumer behaviour as a prerequisite for environmental protection. Journal of Consumer Policy Journal of Consumer Policy, 18(4), 345-385.

Onwezen, M., Bartels, J., \& Antonides, G. (2014). Environmentally consumer choices: Cultural differences in the self-regulatory function of anticipated pride and guilt. Journal of Environmental Psychology, 40, 239-248. https://doi.org/10.1016/j.jenvp.2014.07.003

Park, J., \& Ha, S. (2012). Understanding pro-environmental behavior. International Journal of Retail \&amp; 
Distribution Management Intl $J$ of Retail \&amp; Distrib Mgt, 40(5), 388-403. https://doi.org/10.1108/09590551211222367

Peattie, K., \& Peattie, S. (2009). Social Marketing: A Pathway to Consumption Reduction? Journal of Business Research, 62(2), 260-268. https://doi.org/10.1016/j.jbusres.2008.01.033

Peloza, J., \& Shang, J. (2011). How can corporate social responsibility activities create value for stakeholders? A systematic review. Journal of the Academy Marketing Science, 39, 117-135.

Perella, M. (2013, June 18). Cosmetic industry must do more to leverage greener consumption. Retrieved Septermber 25, 2014, from http:www.edi.net/news/5/cosmetcs-industry

Pickett-Baker, J., \& Ozaki, R. (2008). Pro-environmental Products: Marketing Influence on Consumer Purchase Decision. Journal of Consumer Marketing, 25(5), 281-293. https://doi.org/10.1108/07363760810890516

Polonsky, M. J. (1994). An Introduction To Green Marketing. Electronic Green Journal.

Rex, E., \& Baumann, H. (2006). Beyond Ecolabels: What Green Marketing Can Learn From Conventional Marketing. Journal of Cleaner Production, 15(6), 567-576. https://doi.org/10.1016/j.jclepro.2006.05.013

Rezai, G., Phuah, K., Mohammed, Z., \& Shamsudin, M. (2013). Going Green: Survey of Perceptions and Intentions Among Malaysian Consumers. International Business and Management, 6(1), 104-112. http://dx.doi.org/10.3968/j.ibm.1923842820130601.1125

Robinson, S. R., Irmak, C., \& Jayachandran, S. (2012). Choice of cause in cause-related marketing. Journal of Marketing, 76, 126-139. https://doi.org/10.1509/jm.09.0589

Saha, M., \& Darnton, G. (2005). Green companies or green con-panies: Are companies really green or are they pretending to be? Business and Society Review, 110(2), 117-157. https://doi.org/10.1111/j.0045-3609.2005.00007.x

Schwartz, S. (1977). Normative Influence on Altruism. ADV Experimental Social Psychology, 10, 222-275.

Schwartz, S., \& Howard, J. (1981). A normative decision-making model of altruism. Altruism and Helping Behavior, 89-211.

Shabbir, S., Kaufmann, H. R., Ahmad, I., \& Qureshi, I. M. (2010). Cause related marketing and consumer purchase intentions: The mediating role of brand awareness and corporate image. African Journal of Business Management, 4(6), 1229-1235.

Sheikh, S. R., \& Beise-Zee, R. (2011). Corporate social responsibility or cause-related marketing? The role of cause specificity of CSR. Journal of Consumer Marketing, 28(1), 27-39. https://doi.org/10.1108/07363761111101921

Simmons, C. J. \& Becker-Olsen, K. L. (2006). Achieving marketing objectives through social sponsorship. Journal of Marketing, 70, 154-169.

Steg, L., \& Groot, J. (2010). Explaining prosocial intentions: Testing causal relationships in the norm activation model. British Journal of Social Psychology, 49, 725-743. https:// doi.org/10.1348/014466609X477745

Steinhorst, J., Klöckner, C., \& Matthies, E. (2015). Saving electricity - for the money or the environment? Risks of limiting pro-environmental spillover when using monetary framing. Journal of Environmental Psychology, 125-135. https:// dx.doi.org/10.1016/j.jenvp.2015.05.012

Suki, N., Suki, N., \& Azman, N. (2016). Impacts of corporate social responsibility on the links between green marketing awareness and consumer purchase intentions. Procedia Economics and Finance, 37, 262-269. https://doi.org/10.1016/S2212-5671(16)30123-X

Tan, B., \& Lau, T. (2010). Attitude towards the environment and green products: Consumers"e perspective. Management Science and Engineering, 4(2), 27-39.

Thøgersen, J. (1999). Spillover processes in the development of a sustainable consumption pattern. Journal of Economic Psychology, 20(1), 53-81. https://doi.org/10.1016/S0167-4870(98)00043-9

Thøgersen, J. (2002). Promoting green consumer behavior with eco-labels. New Tools for Environmental Protection: Education, Information, and Voluntary Measures, 83-104.

Tiwari, S., Tripathi, D. M., \& Srivastava, U. (2011). Green marketing: Emerging dimensions. Journal of Business Excellence, 2(1), 18-23.

Van Dam, Y. K., \& Apeldoorn, P. A. C. (1996). Sustainable Marketing. Journal of Macromarketing, 16(2), 45-56. 
Van der Werff, E. \& Steg, L. (2015). One model to predict them all: Predicting energy behaviours with the norm activation model. Energy Research \&amp; Social Science, 6, 8-14. https:// doi.org/10.1016/j.erss.2014.11.002

Vaske, J. J., Jacobs, M. H., Espinosa, T. K. (2015). Carbon footprint mitigation on vacation: A norm activation model. Journal of Outdoor Recreation and Tourism, 11, 80-86. https:// doi.org/10.1016/j.jort.2015.05.002

Verplanken, B, \& Wood, W. (2006). Interventions to break and create consumer habits. Journal of Public Policy and Marketing, 25(1), 90-102. https:// doi.org/10.1509/jppm.25.1.90

Watanatada, P. (2011, March 10). Questioning and evolving the eco-label. Retrieved June 23, 2014 from $\mathrm{http}: / /$ www.theguardian.com/sustainable-business/blog/questioning-evolving-the-ecolabel

Wells, V., Ponting, C., \& Peattie, K. (2011). Behaviour and climate change: Consumer perceptions of responsibility. Journal of Marketing Management, 27(7-8), 808-833. https://doi.org/10.1080/0267257X.2010.500136

Wheeland, M. (2011, February 3). How to Spur Behavior Change to Promote Sustainable Consumers. Retrieved June 23, 2014 from http://www.greenbiz.com/blog/2011/02/03/how-spur-behavior-change-promote-sustainable-consumers

Wigley, S. (2008). Gauging consumers; responses to CSR activities: Does increase awareness make cents? Public Relation Review, 34(3), 306- 308. https:// doi.org/10.1016/j.pubrev.2008.03.034

Yang, D., Lu, Y., Zhu, W., \& Su, C. (2015). Going green: How different advertising appeals impact green consumption behavior. Journal of Business Research. https:// doi.org/10.1016/j.jbusres.2015.04.004

Young, W., Hwang, K., McDonald, S., \& Oates, C. (2010). Sustainable Consumption: Green Consumer Behaviour When Purchasing Products. Sustainable Development. https:// doi.org/10.1002/sd.394

Zhang, Y., Wang, Z., \& Zhou, G. (2013). Antecedents of employee electricity saving behavior in organizations: An empirical study based on norm activation model. Energy Policy, 62, 1120-1127. https://doi.org/10.1016/j.enpol.2013.07.036

Zhang, Y., Zhang, H., Zhang, J., \& Cheng, S. (2014). Predicting residents' pro-environmental behaviors at tourist sites: The role of awareness of disaster's consequences, values, and place attachment. Journal of Environmental Psychology, 40, 131-146. https://doi.org/10.1016/j.jenvp.2014.06.001

Zhu, B. (2013). The Impact of Green Advertising on Consumer Purchase Intention of Green Products. SSRN Journal SSRN Electronic Journal, 3(3), 72-80.

\section{Copyrights}

Copyright for this article is retained by the author(s), with first publication rights granted to the journal.

This is an open-access article distributed under the terms and conditions of the Creative Commons Attribution license (http://creativecommons.org/licenses/by/4.0/). 